\title{
The Relationship between Language Learners' Willingness to Communicate and Their Oral Language Proficiency with Regard to Gender Differences
}

\author{
Amir Valadi \\ Department of Foreign Languages and Literature, Payame Noor University, Iran \\ E-mail: a_valadi@yahoo.com \\ Afshin Rezaee (Corresponding author) \\ Department of TEFL, Shahid Chamran University, Ahwaz, Iran \\ E-mail: afshinrezaee50@gmail.com \\ Parisa Kogani Baharvand \\ Department of TEFL, Lorestan Univesity, Khoramabad, Iran \\ E-mail: parisakoganibaharvand@yahoo.com
}

Received: 02-02- 2015

Published: 01-09- 2015
Accepted: 14-04- 2015

Advance Access Published: May 2015

doi:10.7575/aiac.ijalel.v.4n.5p.147 URL: http://dx.doi.org/10.7575/aiac.ijalel.v.4n.5p.147

\begin{abstract}
Willingness to communicate (WTC), which is defined as the intention to communicate given a choice, continues to establish itself as a determining construct in bringing about success or failure in learning a second language (Dörnyei, 2005, Peng \& Woodrow, 2010). The majority of studies done on the issue are oriented towards ESL contexts leaving us with a gap in English as a foreign language (EFL) context literature. The paucity of studies in EFL contexts caused us to investigate whether WTC and language learners' oral proficiency were related in an Iranian context. To this end, 70 male and female intermediate language learners learning English at a private institute were chosen as the participants of the study. The WTC questionnaire was given to the participants and a standard speaking test was administered. Also, individual semi-structured interviews with some of the participants were used to obtain supportive data. The results of correlational analyses revealed that there was a strong relationship between learners' WTC and their oral proficiency with no significant gender difference. The possible reasons for the correlation are discussed with regard to different motivational, contextual, and attitudinal factors.
\end{abstract}

Keywords: Willingness to communicate, EFL/ESL contexts, Individual differences, Speaking proficiency

\section{Introduction}

Due to variability intrinsic to human behavior, social theories do not apply to all human beings even when all environmental factors are held constant. So any attempt to bring meaningfulness to this variability is overshadowed by individual differences (IDs). Language learners are not immune to these IDs which are defined as "characteristics or traits in respect of which individuals may be shown to differ from each other" (Dörnyei, 2005, p.1). In order to account for the differences in learners' rate and degree of success in learning a second or foreign language, second language acquisition (SLA) researchers have come up with a series of ID variables such as attitudes, motivation, self-esteem, and language anxiety (See Brown, 2014; Ellis, 2008).

One of the ID variables new to SLA scene is WTC defined as "an underlying continuum representing the predisposition toward or away from communicating given the choice" (MacIntyre, Baker, Clément, \& Donovan, 2003, p. 538), or, put it simply, "the intention to initiate communication, given a choice" (McIntyre, Baker, Clément \& Conord, 2001, p. 369). The WTC concept was first developed in L1 communication by McCroskey and his associates. (See McCroskey, 1991 ; McCroskey \& Richmond, 1987). The principal proponent of the adaptation of this L1 construct for L 2 studies was Peter McIntyre, but as MacIntyre, Baker, Clément, and Donovan (2003) pointed out, the need to conceptualize an ID variable that would explain the willingness to talk in contrast to the necessary aptitude was actually expressed as early as 1989 by Skehan when he wrote,"dealing with the willingness different learners have to talk in order to learn....a non-cognitive ID, may be altogether more elusive for researchers" (p.48).

Considering that individuals' WTC is affected by a number of factors many factors such as fear of speaking, lack of self-esteem, and whether individuals are introvert or extrovert (McCroskey, 1992), issues remain as to what possible impacts WTC has on L2 learning. In order to estimate the level of WTC when communicating in an L2, it is necessary to identify individual's reactions to conversation. When presented with an opportunity to use their L2, some individuals 
choose to spark up conversation, and some choose not to get involved. Therefore, WTC represents the psychological preparedness to use an L2 when opportunities arise (MacIntyre, 2007).

It is assumed that learning a second language and the ability to communicate in that language are function of WTC levels. In other words, the higher WTC a speaker has, the more likely s/he is to succeed in L2 acquisition. It has been shown that higher levels of WTC are associated with increased frequency and amount of communication (Richmond \& Kouch, 1992). When the opportunity for using the L2 arises, it is not unusual to be of two minds! One mind wishes to approach the opportunity and the other wishes to withdraw from it (MacIntyre \& MacKinnon, 2007). So, if one determines the contributing factors in the learner's choice of the first alternative, i.e., to approach the use of the L2, one has, in fact, created a successful learning situation. According to MacIntyre (2007), one can identify both individual factors (such as anxiety, motivation, attitudes, interpersonal attraction, etc.) and social contextual factors (such as ethno linguistic vitality, language contact, etc.) that either enhance or reduce WTC. The point to bear in mind is that these factors may interact as a person chooses to speak in the L2.

MacIntyre, Clément, Dörnyei, and Noels (1998) have devised a willingness to communicate model (see Figure1) in which different components contributing to a person's WTC have been displayed. As McIntyre, Baker, Clément, \& Donovan (2002) note, individuals display consistent tendency in their predisposition toward or away from communicating given the choice. In one's first language, WTC is a fairly stable personality trait developing across time and resulting in a "global, personality-based orientation toward talking" (MacIntyre et.al, 2003. p. 591). However, in the case of L2 use, the situation gets more convoluted because individuals' levels of L2 proficiency in general and their L2 communicative competence in particular are additional powerful modifying variables. Thus, MacIntyre et. al. (1998) argued for conceptualizing L2 WTC as a situation-specific construct that includes both state and trait characteristics, and they defined the concept as the individual's readiness to enter into discourse at a particular time with a specific persons using L2. Accordingly, they proposed a multi-layered "pyramid model" under which they subsumed a range of linguistic and psychological variables including linguistic self-confidence (both state and trait), the desire to affiliate with a person, interpersonal motivation, intergroup attitudes, motivation and climate, parameters of the social situation, communicative competence, experience, and various personality traits (see Figure 1).

Although the pyramid model (Figure 1) offers a clear representation of the multiple layers and variables feeding into the behavioral intention of WTC, it fails to describe the interrelationship among the components and their contribution to individuals' level of WTC.

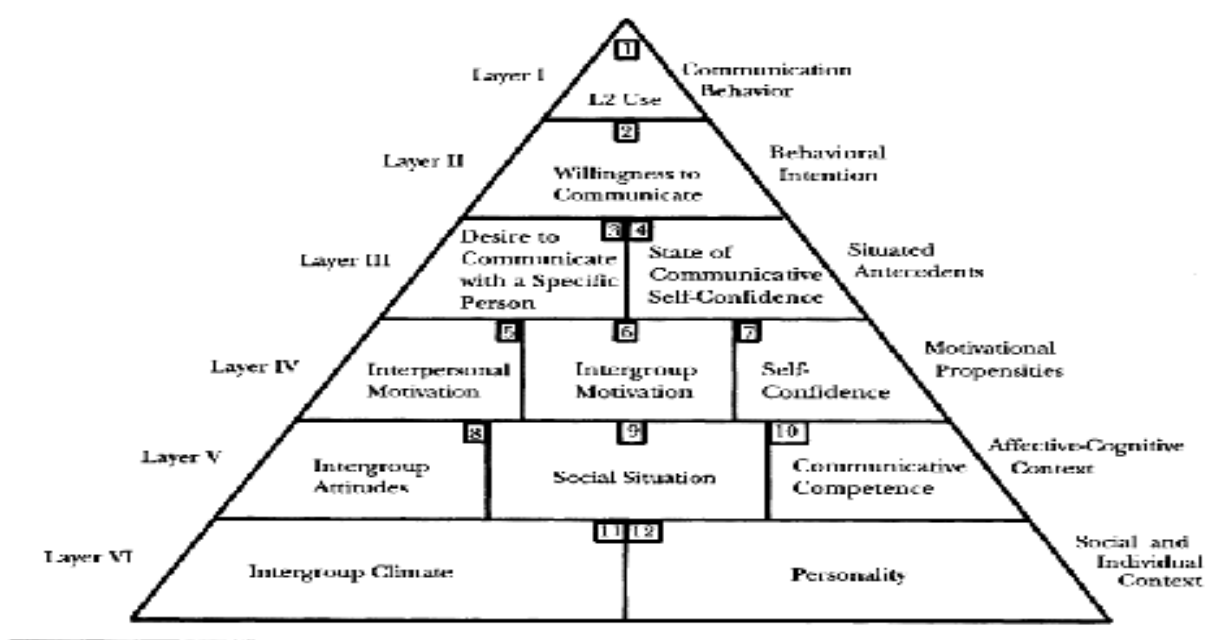

Figure1. Schematic representation of WTC constructs from MacIntyre, Clément, Dörnyei, and Noels (1998).

\section{Review of Literature}

Literature on WTC is not short on original studies which have contributed to a better depiction of the relationship between WTC and other components of second language learning. Hashimoto (2002), for example, conducted a study to find out how WTC of Japanese learners of English as a second language and their motivation to use English were related. Based on the model discussed earlier, the findings revealed that motivation and WTC together could predict the frequency of communication in classroom contexts. In another study, Clément et. al. (2003) aimed at investigating WTC and social context models together to probe the role of individuals and social factors in triggering the use of L2 in a group of Anglophone and Francophone students in Canada. The researchers concluded that in comparison with Anglophone students who were learning French as their second language the Francophone learners of English as a second language who constituted the language minority in Canada were more willing to communicate in L2, and they were found to be more self-confident in classroom communication.

Yashima, Zenuk-Nishde, and Shimizu (2004) studied 160 adult learners of English as a second language to find out how WTC in English would affect the frequency of classroom communication. In the first phase of their data analysis, the researchers concluded that learner's WTC is directly related to self-confidence and indirectly to motivation. 
According to the results in the second phase of analysis, a significant relationship between the frequency of communication and WTC in English was found. To sum up, according to Cao and Philip (2006) other variables such as group size, familiarity with interlocutors, interlocutors' participation, familiarity with topic under discussion, selfconfidence, medium of communication, and cultural background were also found to affect learners' WTC levels.

In the Iranian EFL context, Baghaei and Dourakhshan (2012) carried out a study to explore the relationship between WTC components and success in learning a foreign language. For the purposes of the researchers'study, a willingness to communicate scale was correlated with a $\mathrm{C}$-Test which was used in the study as a measure of general language proficiency. The results showed that two out of the three subscales of WTC, namely willingness to communicate in school content and willingness to with native speakers of English, were moderately correlated with success in learning English as a foreign language. The third subscale of WTC, i.e., willingness to communicate with non-native speakers of English, was not found to be statistically correlated with learning a foreign language. In another Iranian, Shahsavani, Shasavar, and Sahragard (2014) set out to explore the relationship between WTC and identity processing styles among advanced Iranian learners of English as a foreign language. The WTC and identity processing styles of 375 advanced EFL Iranian learners were assessed using WTC questionnaires. According to the finding of the study, the information identity processing style was the strongest predictor of WTC levels. Furthermore, the result of multiple regressions indicated that identity style subscale could account for $77 \%$ of WTC variance.

Although WTC has established itself as a concern of SLA researchers and accrued a literature of its own, this subject seems to have escaped many of the EFL researchers' attention, and, in fact, few studies have gone to delve into the WTC construct. Issues have remained on the possible ways for raising this valuable construct among the EFL learners. It seems that, as a starting point, the need for doing correlational studies on the issue is deeply felt. In the Iranian context, as an EFL context, there is a common sense that female learners outperform male ones in terms of oral language proficiency, something that is ascribed to the girls' WTC abilities. These concerns have been formulate into the following research questions:

1. Is there any significant relationship between language learners' willingness to communicate and their speaking proficiency in an EFL context?

2. Are male and female students different in this regard?

\section{Method}

\subsection{Participants}

Participants of the study were selected randomly from two branches of Iran Language Institute, Khoramabad, Iran. Given the non-coeducational policy of the institute, we had two gender-based groups: female group $(n=70)$ and male group $(\mathrm{n}=70)$. Based on the institute's placement criteria, they were intermediate students and their age ranged from 15 to 30 years old. The mean length of learning English was four to five hours a week. All the four skills, especially speaking, were worked on and emphasized in the institutes. The participants were trained by the same teaching method and they studied the same textbooks under the instruction of proficient English language teachers. The institute followed standard teaching practices and all language teachers were required to follow the classroom procedures of the institute.

\subsection{Procedure}

In order to measure the learners' WTC levels, a modified version of the Likert-type questionnaire developed by MacIntyre et al. (2001) and Baghai and Dourakhshan (2011) was distributed among the participants. Furthermore, a few context-bound adaptation were made to the items. The questionnaire (see the appendix) includes 25 items relevant to the factors contributing to WTC in learning a second language. The questionnaire items were translated into participants' native language (Persian) to avoid any possible misunderstandings and to increase the validity of responses. To ensure parallelism with the English versions of the questionnaires, the questionnaire items were translated by one of the researchers in this study and subsequently verified by a professional translator. The questionnaire followed a Likerttype scale ranging from strongly disagree (1) to strongly agree (5). The learners were asked to indicate their responses to the items across the continuum. Reliability checks on the questionnaire based on a pilot study yielded an alpha estimate of 0.87. Along with the questionnaire, short interviews were held with some of the participants randomly to approve their responses. In addition, in order to measure students' speaking ability, along with administration of the institute tests, the teachers' judgment of the language learners was used to confirm the obtained results. To prevent the participants from running through the questionnaire items they were given enough time. The speaking test was administered at the end of the course to estimate the speaking ability scores.

\subsection{Data analysis}

The SPSS version 20 was employed to estimate statistical numbers, The Pearson correlation formula clarified the kind and amount of correlation between WTC level and speaking proficiency. To find out whether there was a significant difference between the two groups in terms of their levels of WTC, an in dependent-samples t-test was run.

\section{Results}

Our first research question concerned the relationship between the participant willingness to communicate and their speaking proficiency. Table 1 presents the descriptive statistics of the two variables. 
Table 1. The Descriptive Statistics for the Participants' Dual scores

\begin{tabular}{cccc}
\hline & Mean & Std. Deviation & N \\
\hline Speaking & 80.9214 & 7.02930 & 140 \\
\hline WTC & 19.9714 & 6.26621 & 140 \\
\hline
\end{tabular}

The relationship between WTC levels (as measured by the WTC questionnaire) and speaking proficiency of the participants (as measured by the speaking proficiency test) was investigated using Pearson product-moment correlation coefficient. Preliminary analysis revealed that the assumptions of normality, linearity and homoscedasticity were not violated. There was a strong correlation between the two variables, $(\mathrm{r}=.356, \mathrm{n}=140, \mathrm{p}<.005)$ with high levels of perceived control associated with lower levels perceived stress, showing that there was a positive correlation between the participants' willingness to communicate and their speaking proficiency.

Table 2. Pearson Product-moment Correlation Coefficient for Speaking and WTC Scores

\begin{tabular}{cllc}
\hline & & Speaking & WTC \\
\hline \multirow{2}{*}{ Speaking } & Pearson Correlation & 1 & $.356^{* *}$ \\
\cline { 2 - 4 } & Sig. (2-tailed) & .000 \\
\cline { 2 - 4 } & $\mathrm{N}$ & 140 & 140 \\
\hline & Pearson Correlation & $.356^{* *}$ & 1 \\
\cline { 2 - 4 } & Sig. (2-tailed) & .000 & 140
\end{tabular}

**. Correlation is significant at the 0.01 level (2-tailed).

Our second question concerned the relationship between participants' WTC and their gender. The relevant descriptive statistics have been presented in Table 3 .

Table 3. The Descriptive Statistics for Gender and WTC

\begin{tabular}{cccccc}
\hline \multirow{2}{*}{ participants } & N & Mean & Std. Deviation & $\begin{array}{c}\text { Std. Error } \\
\text { Mean }\end{array}$ \\
\hline \multirow{2}{*}{ Score } & female & 70 & 20.3286 & 8.25977 & .98723 \\
\cline { 2 - 6 } & male & 70 & 19.6143 & 3.25840 & .38945 \\
\hline
\end{tabular}

As it can be seen in Table 4, an independent-samples t-test was conducted to compare the scores for males and females. There was no significant difference in WTC scores for males $(\mathrm{M}=19.61, \mathrm{SD}=3.25)$; $\mathrm{t}(138)=0.673, \mathrm{p}=0.502)$, and females $(\mathrm{M}=20.32, \mathrm{SD}=8.25)$. The magnitude of the differences in the means was very...., meaning that gender did not influence the participants' levels of WTC.

Table 4. T-test for Gender and WTC

\begin{tabular}{|c|c|c|c|c|c|c|c|c|c|c|}
\hline & & \multicolumn{2}{|c|}{$\begin{array}{c}\text { Levene's Test } \\
\text { for Equality of } \\
\text { Variances }\end{array}$} & \multicolumn{7}{|c|}{ t-test for Equality of Means } \\
\hline & & \multirow[t]{2}{*}{$\mathrm{F}$} & \multirow[t]{2}{*}{ Sig. } & \multirow[t]{2}{*}{$\mathrm{t}$} & \multirow[t]{2}{*}{$\mathrm{df}$} & \multirow[t]{2}{*}{$\begin{array}{l}\text { Sig. }(2- \\
\text { tailed) }\end{array}$} & \multirow[t]{2}{*}{$\begin{array}{l}\text { Mean } \\
\text { Differen } \\
\text { ce }\end{array}$} & \multirow{2}{*}{$\begin{array}{c}\text { Std. } \\
\text { Error } \\
\text { Differen } \\
\text { ce }\end{array}$} & \multicolumn{2}{|c|}{$\begin{array}{l}95 \% \text { Confidence } \\
\text { Interval of the } \\
\text { Difference }\end{array}$} \\
\hline & & & & & & & & & Lower & Upper \\
\hline \multirow{2}{*}{ score } & $\begin{array}{l}\text { Equal variances } \\
\text { assumed }\end{array}$ & 2.320 & .130 & .673 & 138 & .502 & .71429 & 1.06127 & -1.38417 & 2.81274 \\
\hline & $\begin{array}{l}\text { Equal variances not } \\
\text { assumed }\end{array}$ & & & .673 & 89.968 & .503 & .71429 & 1.06127 & -1.39413 & 2.82270 \\
\hline
\end{tabular}




\section{Discussion}

This study can be considered as one of the few studies which focused on demographic and educational aspects of the concept of WTC in a specific educational setting like that of Iran. Before discussing the finding of the study caution should be exercised when it comes to interpreting reported results since the bulk of the available WTC literature is not directly related to the research questions we have addressed in the research project, that is, the reported results should be cautiously interpreted in the light of the accrued literature.

This study set out to investigate the relationship between a group of Iranian EFL language learners' willingness to communicate and their speaking proficiency, on the one hand, and to examine the relationship between gender and WTC, on the other hand. According to the findings of the study, there was a positive and strong relationship between the learners' WTC levels and their speaking proficiency. One possible explanation for this is that the desire to communicate can enhance learners' interpersonal motivation, intergroup motivation, self-confidence, intergroup attitudes, social situation, communicative competence, intergroup climate, and personality as Mohsen and Niknejad( 2013) previously found about.

These findings of the study can also be accounted for by the fact that in EFL contexts where language input is most of the time meager, and language learners have no out-of-classroom exposure to the language they are learning, those who are more willing to communicate can be better language input generators, and this according to Ellis (2008) plays a crucial role in language learners' oral proficiency.

The second research question dealt with the difference between male and female students in terms of their willingness to communicate. This was worth exploring because the relevant literature on the issue is inconclusive. As shown in the result section, there was no significant difference between male and female participants with regard to their WTC. This finding is supported by those reported by Baker and McIntyre (2000). These researchers studied an immersion and nonimmersion students' willingness to communicate in the L2 and found no statistically significant difference between male and female immersion students. Hence, no conclusive claim can be made regarding gender-based differences regarding WTC because a myriad of modifying socio-political factors are at work in every specific educational contexts. That is, replicating such studies in different socio-political context might result in different results

Furthermore, it should be noted that there was a close relationship between the results obtained from the quantitative analysis of the data and those from the qualitative analysis of the interview we had with a number of the participants. Having interviewed some of the participants with high WTC scores, we found a number of most attested factors contributing to WTC among the Iranian learners:

- Learning English is really interesting for them.

- They do not prefer an English class which is teacher-centered and, in which students are silent.

- In order to improve their English, they are willing to talk in English with their classmates inside and outside the class.

- They try to use English for texting or exchanging e-mails.

It could be claimed that a significant positive correlation between learners' speaking proficiency and their WTC indicates that the learners found the classroom environment pleasant and friendly. This view is supported by Mohseni and Niknejad's (2013) idea that context plays an important role in encouraging learners to open a conversation.

\section{Conclusion and Implications}

It has been empirically shown that WTC is one of the factors influencing language learners' propensity to communicate in an ESL and EFL context. WTC can be both enduring and situational, meaning that numerous factors surrounding learners might affect their decisions to communicate their meanings through L2 language they are learning. Research on WTC in first and second language context abounds (Cetinkaya, 2007; Yashima, 2002); however, not much research has been carried out in foreign contexts where English is most often used for academic purposes. Thus the present study investigated the impact of WTC on speaking proficiency. Another aim was to investigate whether male and female students differ in terms of WTC in EFL context.

According to the findings of the study, there was a strong correlation between the participants' WTC level and their oral proficiency. That is, those students having a high level of WTC to open up a conversation are more competent in speaking ability in the classroom. The obtained results were in line with Wang's (2004) study which identified WTC and writing ability as two variables positively correlated. In another study, Baghaei and Dourakhshan (2012) found a moderate correlation between WTC and English proficiency among EFL learners which their conclusion is supported by the result of the present study.

Based on the findings of the study at hand, gender doesn't contribute to students' willingness to communicate in an EFL educational setting. According to the results of the analysis, there was not a significant difference between male and female students in terms of WTC. This result is in contrast to the findings of the study conducted by Ahmadian and Shirvani (2012) that showed that there was a significant difference between male and female in respect to their WTC in Iranian EFL context. As mentioned earlier, gender difference must be accompanied by a number of other sociopolitical factors if we want to get a clear picture of the role that gender can play.

The study's most important implication is that with growing awareness of different issues, such as WTC in language classrooms, instructors need to translate research results into practical instruction. Language instructors should be aware 
of how they can promote students WTC. They should cover broad areas such as motivating learners to learn English by communicating with it, creating a positive and pleasant environment when speaking in English, and trying to make classroom student-centered rather than teacher-dominated. As has been attested in the related literature, the ultimate goal of any language instruction program is to help language learner move from explicit and formal knowledge to implicit and spontaneous language use. It goes without saying that raising more WTC among the language learners can be one of the first steps that can be taken.

\section{References}

Ahmadian, M., \& Shirvani, K. (2012). The role of gender and academic experience in EFL students' willingness to communicate in English in academic context. Presented at Lorestan National English Conference. October, 2012.

Baghaei, P. \& Durakhshan, A. (2012). The relationship between willingness to communicate and success in learning English as a foreign language. Elixir psychology, 53.

Baker, S.C., \& MacIntyre, P.D. (2000).and second language orientation. Language learning, 50(2), 311 - 371.

Brown, H. (2014). Principles of language learning and teaching $\left(6^{\text {th }} \mathrm{ed}\right)$. New York: Longman.

Cao, Y., Philip, J. (2006). Interactional context and willingness to communicate; A comparison of behavior of whole class, group and dyadic interaction. The role of gender in communication System 37, 480- 493.

Cetinkaya B, Y. (2007). Turkish students' willingness to communicate in English. DokuzEylülüniversiy, BucaEducation Faculty Journal, 21, 115- 123.

Clément, R., Baker, S.C., \& MacIntyre, P.D, (2003). Willingness to communicate in a second language: The effect of context, norms, and vitality. Journal of language and social psychology; 22(2), 190- 209.

Dörnyei, Z. (2005). The psychology of the language learner. Lawrence Erlbaum.

Ellis, R. (2008). The study of second acquisition. Oxford: Oxford University Press.

Hashimoto, T. (2002). The constructive approach to the dynamical view of language. In AngeloCangelos, and DomenicoParisi, editors, simulating the evolution of language 307-324. London: Springer Verlage.

MacIntyre, P.D., (2007). Willingness to communicate in the second language: Understanding the decision to speak as a volitional process. Modern language journal 91. 564- 576.

MacIntyre, P.D, \& Mackinnon, S.P. (2007). Embracing affective ambivalence: A research agenda for understanding the interdependent processes of language anxiety and motivation. Presented at city university of Hong Kong. June, 2007.

MacIntyre, P.D., Baker, S.C., Clément, R., \& Donovan, L.A. (2002). Sex and age effects on willingness to communicate, anxiety, perceived competence, and L2 motivation among Junior high school French immersion students. Language learning, 52, 537- 564.

MacIntyre, P.D., Baker, S.C, Clément, R., \& Conrod, S. (2001). Willingness to communicate, social support and language learning orientation of Immersion student. Studies in second language Acquisition. 23(3). 369- 388.

MacIntyre, P.D., Babin, P.A., \& Clément, K, (1991). Willingness to communicate: Antecedents and consequence. Communication Quarterly, 47 (2), 215- 229.

MacIntyre, P.D., Clément, R., Dörnyei, Z., Noels, K.A. (1998). Conceptualizing willingness to communicate in a $\mathrm{L}_{2}$ : A situational model of L2 confidence and affiliation. Modern language Journal. 82(4) - 545-562.

MacIntyre, P.D. \& Charos, C. (1996). Personality, attitudes, and affect as predictors of second language communication. Journal of language and social psychology, 15(1), 3- 26.

McCroskey, J.C. (1992). Reliability and validity of the willingness to communicate scale. Communication Quarterly, 40, 16- 25.

McCroskey, J.C. \& Richmond, V.P. (1987).Willingness to communicate. IN J.C. McCroskey \& J.A. Daily (Eds). Personality and interpersonal communication (PP. 139-156). Newbury Park, CA: sage.

Peng J, E. \& Woodrow, L. (2010). Willingness to communicate in English: A model in the Chinese EFL classroom context. Language learning, 60, 834-76.

Richmond, V.P., \& Koach, K.D (1992). Willingness to communicate and employee success in U.S. organization. Journal of Applied communication Research, 20, 95-115.

Shahsavani, S., Shahsavari, Z., Sahragard, R. (2014). On the relationship between willingness to communicate and identity processing styles of the Iranian advanced EFL learners. (online): 2289-2737.

Skehan, P. (1989). Individual differences in second language learning. London: Edward Aronld.

Yashima, T. (2002). Willingness to communicate in a second language: The Japanese EFL context. The modern Language Journal, 86(1).54- 56.

Yashima, T. Zenuk-Nishide, L., Shimizu, K. (2004). The influence of attitudes and affect on willingness to communicate and second language communication. Language learning, 54:1, 119-152. 


\section{Appendix}

The Questionnaire to measure willingness to communicate

Student's Name: ...............................

The following questions ask about your willingness to communicate in learning the English language. Remember, there are no right or wrong answers, just answer as accurately as possible. Use the scale below to answer the questions.

$$
1=\text { strongly disagree } \quad 2=\text { disagree } \quad 3=\text { no idea } \quad 4=\text { agree } \quad 5=\text { strongly agree }
$$

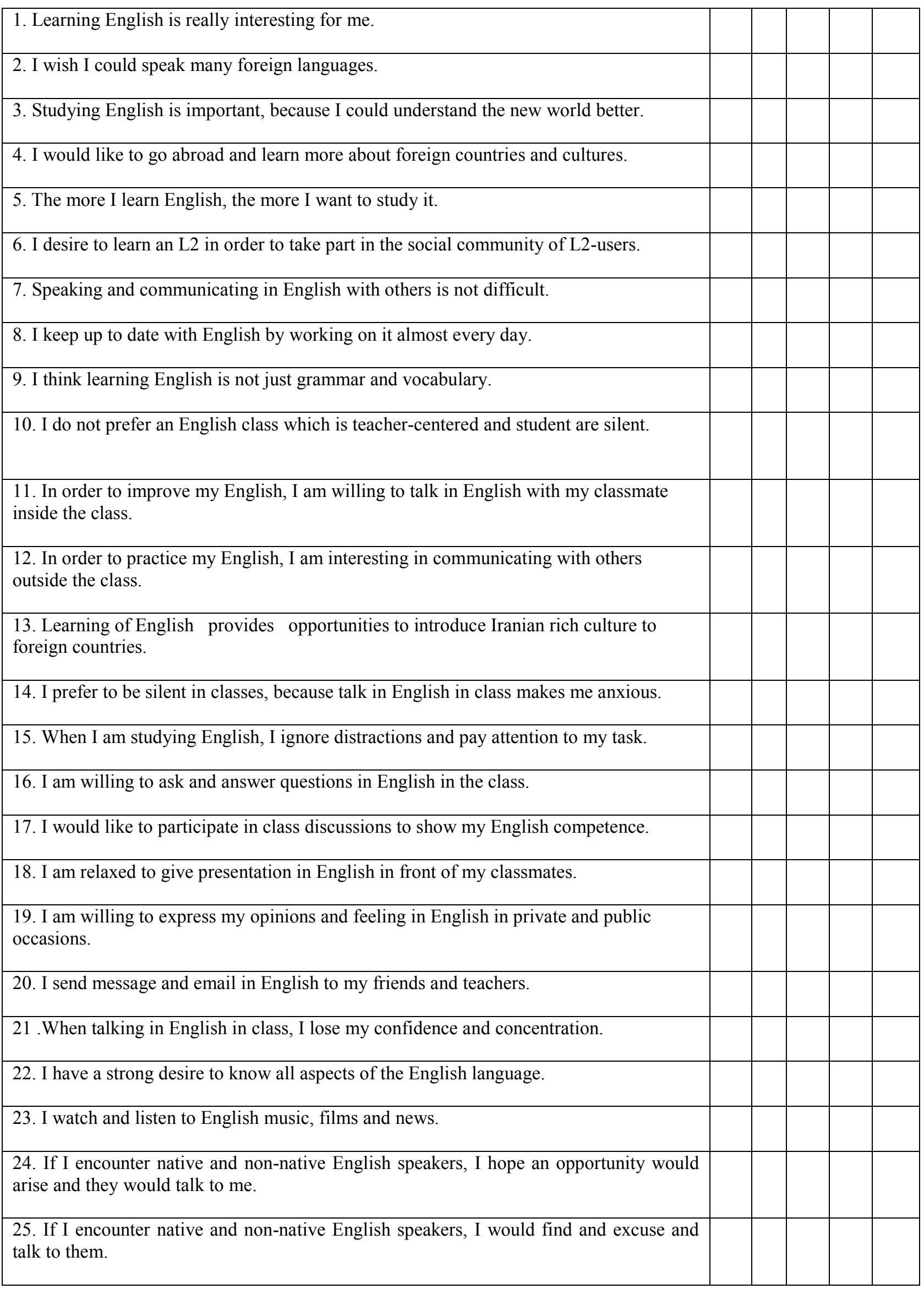

